\title{
The impact of financial integration on economic growth Case of Maghreb countries
}

\author{
Saoussen Kouki \\ Department of Economics \\ Faculty of Economic Sciences and Management, Tunisia \\ Sami Rezgui \\ Department of Quantitative Methods \\ Faculty of Economic Sciences and Management, Tunisia
}

\begin{abstract}
The relationship between financial integration and economic growth is a vital subject. Many empirical and theoretical works affirmed that financial integration could help countries to increase their growth rate and ameliorate their life quality. The target of this work is to study financial integration effects of thirty-five years, from January 1981 until December 2014, on economic growth of the three Maghreb countries (Algeria, Morocco and Tunisia) using the ARDL approach to cointegration testing. Estimations results indicate that financial integration affects positively the economic growth of the Maghreb countries.
\end{abstract}

Keywords: financial integration, economic growth, Maghreb countries, ARDL approach.

\section{INTRODUCTION}

The international financial integration is a very old phenomenon, its origins date back to the late $19^{\text {th }}$ century, specifically 1870 , during that period, the financial markets were in need of new global markets in order to invest and find more funding means. The relationship between financial integration and economic growth has always been of particular interest. Many studies have been devoted to this relationship to confirm or detract from the influence of financial integration on economic growth.

Some economists say that the consequences of integration on economic growth are positive. Obstfeld (1994), Acemoglu and Zilibotti (1997) Bailiu (2000), Honig (2008), klein and Olivei (2008) have shown that the inflow of foreign capital is a factor likely to lead to a transfer of technology, specialization in production, allocation of capital and consequently stimulates economic growth. Thereby, the opening of emerging markets attracted foreign investors and increased the flows of capital towards them. According to Henry (2000), the liberalization of the emerging markets increased the number of foreign investors, which lead to the increase of the financial markets' liquidity, the reduction of the cost of debt, the improvement of profitability of certain projects and the increase of economic activity.

Also the study of Mensi and al (2010) reveals that the direct relationship between financial integration and economic growth is positive and stable. They affirmed that this liberalization of the capital movements influenced positively the integration of the developing economies worldwide. So, the financial integration of the financial markets facilitates the passage from one market to another as it allows the increase of the markets' efficiency. The vast economic transformations imposed by globalization have freed more the capital, facilitated trade, promoted the softening of control systems of exchanges and the establishment of currencies 
convertibility, which increased the economic activity. This environment drove the majority of the Maghreb countries to liberate their trade and to globalize their financial policy due to the positive effect of financial integration on economic growth. The results of the estimates of Soumia and Benhabib (2012) showed that financial integration affects, positively, but slightly differently, the economic growth of the Maghreb countries.

Others argue that financial integration does not promote economic gains, that is, it does not have significant effects on economic growth as demonstrated by Rodrick (1998) and Kraay (1998). This positive relationship is valid only under certain conditions and countries need to lift some strategies to stimulate the real economy.

In this paper, we are trying to explain the impact of financial integration on economic growth in the Maghreb countries, especially, that their markets are of limited size and weak enticement, which hinder their economic growth at the level of competitiveness. Among the countries, which decided to conduct the way of liberalization and financial integration, we are interested in three Maghreb countries: Algeria, Morocco and Tunisia. This work tries to study the following issue: does financial integration allow the Maghreb countries to significantly improve their economic growth rate? The empirical study is based on the works of Edison, H.J., Levine, R., Ricci, L., Slok, T. (2002), Honig (2008) and Mougani (2012) using the ARDL approach to cointegration during the period of 1981-2014.

\section{EMPIRICAL LITERATURE}

The study of the relationship between financial integration and economic growth still is of particular interest (McKinnon and Shaw 1973; Alesina (1994); De Gregorio (1996); Edwards (2001); Prasad and al(2003); Dhrifi (2009); Lane \& Milesi-Ferretti (2003); Klein and Oliver (2008); Ben Salha and al (2008); Mensi and al (2010); Soumia and Benhabib (2012)). These economists showed that the liberalization of the capital account affects positively growth.

A number of researchers demonstrated the existence of an important relationship between financial integration and economic growth that is due to the economic policy pursued by economies in order to well integrate financially and increase productivity. We can explain the relationship between financial integration and economic growth through the important role of trade openness and interest rate, which determine the strategy of the economic policy of an economy.

\section{Financial integration, economic growth and trade openness}

In the early $19^{\text {th }}$ century, David Ricardo demonstrated that the openness of a country allows the redirection of its rare resources towards the more efficient sectors and improves its welfare. Thus, Grossman and Helpman (2014) showed that trade openness directly affects productivity levels in domestic producers with more efficient foreigners and thus increase the contacts of each country with the best practices in the world. They affirmed that trade openness helps to increase local imports of goods and services thanks to the transfer of technologies, which makes the production of a country more efficient and increases its productivity.

Mougani (2012) focused on the impact of private capital flows on economic growth based on the rules of trade openness. Thus he has shown that financial integration affects several aspects of economic performance, particularly increases investment rates, technology transfers, trade openness, stimulates the development of the financial system and economic growth. According to Batra (1992) and Leamer (1985), the liberalization of trade paves the way to eliminate tariffs and thus reduces the relative price of local goods. Therefore, these assets become less attractive than foreign ones, which would affect negatively the national 
economy. However, there are works that encourage protectionist policies but not as a longterm strategy.

Other works, like those of Grossman and Helpman (1991), Romer (1993), Rivera-Batiz and Romer (1991), considered innovation as a source of growth and encourages one economy openness. In their models, they found that earnings from free trade come primarily from scale effects lead by research and development. In addition, the reduction of custom duties and the replacement of non-tariff barriers by custom duties increased the amount of stored merchandises and thus the state revenues.

Razafindrakoto and Roubaud (2005) demonstrated the positive effect of trade on economic growth due to good factors reallocation, access to new technologies and competition within the economies of scale, which succeed to increase productivity. In general, financial integration contributes to the improvement of local financial systems, optimal allocation of financial resources and global diversification of the economy. Based on the works of Tybout (1991), Haddad (1993), Harrison (1996), Dutz (1991) 30, Fecher, Perelman and Pestieau (1993), Manganelli and Popov, (2010), we managed to identify four conclusions about the relationship between economic growth and trade openness:

$\checkmark$ Significant effect of the liberalization of the movement of capital on enterprises productivity;

$\checkmark$ Export firms differ from non-export ones. They are more efficient, larger and pay higher wages;

$\checkmark$ Competition forces local enterprises to adapt to new technologies, reduce technical inefficiencies and improve product quality...;

$\checkmark$ Productivity gains are due to the successful reallocation of human and natural resources, which are more important than gains resulted from the better exploitation of economies of scale.

De Gregorio and Lee (1998) affirmed that the fierce competition within domestic markets and foreign direct investments reduced the profits of local enterprises and minimized the production costs, as it stimulated domestic investment. Martin and Helene (2006) suggested that foreign direct investment (FDI) affects positively the economic growth rate in the longterm.

\section{Financial integration, economic growth and interest rate}

Some financial have shown that raising the interest rate allows for increased profitable investments and reduces risky projects. Rising interest rates or attachment has a negative effect on the second sector Because of the increase in interest rates followed by banks. In this context, Galbis (1977) tried to analyze the positive impact of financial integration on the efficiency of investment. Galbis (1977) was able to show that the use of will reduce the pressure on domestic banks and will give other and other places for investors to realize their projects. On another side this financial liberalization will improve the efficiency of the investment and in this way he savings will move from the traditional sector to the modern sector.

Mckinnom (1973) affirmed that the liberalization of financial system allows the increase of interest rate on deposits. Therefore, it increases the savings rate that plays an important role on economic growth since that the rise in interest rates allows to reduce the projects of lowoutput and helps to develop the banking sector. According to him, financial liberalization is the only driving force to achieve a long-term economic growth. Shaw (1973) also demonstrated 
that financial liberalization promotes the entry of foreign capital and the non-outgoing of domestic capital because of the increase of the interest rates on deposits.

Kapur (1976) is the first economist to develop Mckinnon and Shaw (1973) analysis. He suggested a model whose capital is divided into a moving capital and a static one. He demonstrated that low interest rate prevents borrowers to invest because lenders refuse to give credits, which impede economic growth. However, an increase of the interest rates on deposits enables the raise of loans demand that lead to reduce inflation and increase investments, therefore, increase the economic activity. Galbis (1977) demonstrated that the use of external financing would decrease the pressure on domestic banks and would provide other opportunities and other places so investors could implement their projects. On the other side, this financial liberalization would improve investment efficiency, and in this way savings would move from the traditional sector to the modern sector.

Brezigar-Masten and al. (2008) studied the non-linear effects of financial development and financial integration on European's economic growth using the data of macroeconomic and industrial levels. However, the effects of financial integration become more significant at higher levels of financial development. Likewise, the results demonstrate that monetary integration in Europe contributed significantly to achieve a higher degree of financial integration. So, Arjana Brezigar and al. (2011) tested the hypothesis of the direct financial integration effect on growth through the liberalization of the domestic financial sector.

Then Brigitte. D and Micheal. F (2007) have shown that in an increasingly the real interest rate is determined in large part by the forces exerted on the world market. Moreover, in the case of relatively modest open economies, the domestic situation has little effect on the real global interest rate in the medium and long term. According to the work of Brigitte Desroches and Michael Francis in 2007, we could to conclude that changes in investment demand determining the global interest rate.

\section{MODEL}

Based mainly on the works of Edison, H. J., Levine, R., Ricci, L., Slok, T. (2002), Honig (2008) and Mougani (2012), we tried to write the estimation equation of financial integration effect on economic growth that is the following:

$$
\text { Growth }_{t}=\boldsymbol{\alpha}+\boldsymbol{\beta} \text { FI }_{t}+\lambda X_{t}+\varepsilon_{t}
$$

With $\boldsymbol{\varepsilon}_{\mathbf{t}}$ is an error term of zero mean and constant variance; model parameters measure the variables sensitivity to economic growth.

\section{Dependent variable}

Growth (GDP): refers to economic growth, some economists assume that GDP per capita is the best estimation to get the level of economic integration, which would lead to a larger integration of capital markets. We are going to take into consideration the annual percentage of growth of GDP per capita based on constant local currency. GDP per capita is the gross domestic product divided by the number of population over a one-year period.

\section{Independent variables}

\section{-Financial integration (FI) variable}

There are several financial integration measures but we are going to use Lane and MilesiFerretti one. It is an indicator measured by the stock of accumulated capital flows (the sum of assets and liabilities of foreign direct investment and portfolio flows) with regard to GDP because this indicator better reflects the development of financial integration from one year to another paving us the way to better analyze the possible effects of financial openness on economic growth. 


\section{-Macroeconomic policy variables $(X)$}

-Trade openness (TO) degree: we calculate trade openness degree from the ratio of foreign trade that is the sum of imports and exports on GDP.

-Interest Rate (IR): we are going to take into account the interest rate on deposits and the interest rate paid by commercial banks, or similar, on demand deposits, fixed term deposits and deposits on account.

All the variables are annual data that are provided from the data base of International Financial Statistics (IFS) of the International Monetary Fund and the World Bank.

\section{Econometric study}

There are several econometric techniques to test the long-term relationships between series. The most used ones are Engle and Grander (1987) method and Johansen (1988) approach but these methods require that all series should be integrated of the same order. However, the advantage of ARDL method is that it can be applied to any level of integration of used variables, additionally, this method produces more efficient results for small samples, which is the case of the majority of emerging countries' empirical studies. Thus, we estimate our model by this new technique of cointegration suggested by Pesaran et al. (2001) «Autoregressive Distributed Lag (ARDL) ».

Our study tries to examine the possibility of a long-term relationship between GDP per capita, which reflects the economic growth observed by (Growth: GDP), and financial integration (FI) using cointegration method suggested by Pesaran et al. (2001). We start by briefly describing ARDL technique. This procedure classifies all the variables of the model as endogenous variables. The error-correction model is resulted by the following equation (2):

$$
\begin{aligned}
& \Delta G D P_{t}=a_{0}+\sum_{i-1}^{p} b_{i} \Delta G D P_{t-i}+\sum_{i-0}^{p} c_{i} \Delta F I_{t-i}+\sum_{i-0}^{p} d_{i} \Delta T O_{t-i}+\quad \sum_{i-0}^{p} h_{i} \Delta R I_{t-i} \\
& \delta_{1} G D P_{t-1}+\delta_{2} F I_{t-1}+\delta_{3} T O_{t-1}+\delta_{4} R I_{t-1}+\varepsilon_{t}
\end{aligned}
$$

With $\Delta$ represents the operator of first difference, $\mathrm{a}_{0}$ is the constant, and $\boldsymbol{\varepsilon}_{\mathrm{t}}$ is an error-term of zero mean and constant variance. We start by the estimations of equation (2) using the Ordinary Least Squares Method (OLSM) in order to test the presence of a long-term relationship between variables by the value of Ficher's test to determine the signification of the number of variable lags in our model. We test $\mathrm{H}_{0}: \delta_{1}=\delta_{2}=\delta_{3}=\delta_{4}=0$ versus the hypothesis $\mathrm{H}_{1}$ : $\delta_{1} \neq \delta_{2} \neq \delta_{3} \neq \delta_{4} \neq 0$. If the statistic $\mathrm{F}$ calculated comes out above the threshold of critical values thus the null hypothesis is rejected, which indicates cointegration. If the calculated statistic $F$ is below the threshold of critical values, the null hypothesis cannot be rejected due to the absence of cointegration.

We are going to make the unit root test-to-test stationarity and determine the order of integration of the different variables of each country. 
Table $N^{\circ} 1$ : Unit root test

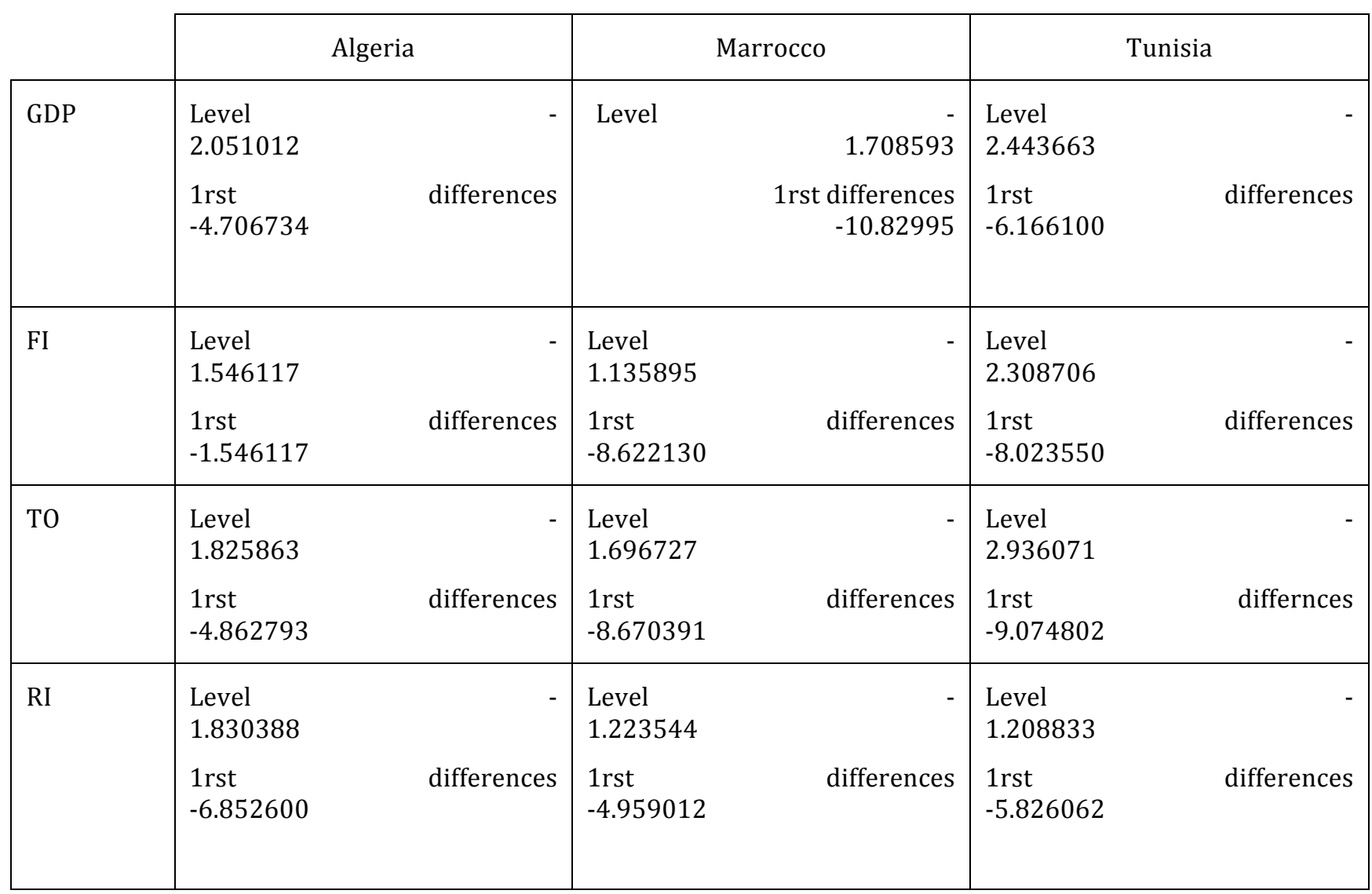

Source: calculation made on eviews 9.0.

All the regression include an intercept in the levels and in the first differences at $5 \%$.

In table $\mathrm{N}^{\circ} 1$, we find that the variables are not stationary and are only stationary in the first difference. Therefore, all variables are integrated of order 1 or I(1). Based on the above unit rate test, we apply the autoregressive cointegration test to determine if there is a linear combination of variables of the model that is cointegrated.

\section{Study of cointegration according ARDL approach}

To analyze the cointegration of variables, it is necessary to determine the number of optimal lag (P) of the autoregressive model VAR based on the values of AIC criteria (Akaike Information Criterion) and SC (Schwarz Criterion). Indeed, the choice of the number of lags could have a major influence on the performance of cointegration tests. 


\section{Table $N^{\circ} 2$ : VAR lag order}

\begin{tabular}{|c|c|c|c|c|c|c|c|}
\hline & Lag & $\log L$ & LR & FPE & AIC & SC & $\mathrm{HQ}$ \\
\hline \multicolumn{8}{|l|}{ Algeria } \\
\hline & 0 & -238.8633 & NA & 3221.901 & 19.42906 & 19.62408 & 19.22721 \\
\hline & 1 & -167.6745 & $113.9020^{*}$ & 39.81782 & $13.69522^{*}$ & $15.98906^{*}$ & $18.43652^{*}$ \\
\hline & 2 & -156.9473 & 13.73084 & 67.99020 & 15.43578 & 17.19097 & 18.81567 \\
\hline \multicolumn{8}{|c|}{ Marrocco } \\
\hline & 0 & -300.7730 & NA & 456117.8 & 24.38184 & 24.57686 & 24.43593 \\
\hline & 1 & -265.3104 & $56.74021 *$ & 98241.64* & 22.82483 & 23.79993* & $23.09528^{*}$ \\
\hline & 2 & -249.2681 & 20.53418 & 109647.5 & 22.82145 & 24.57663 & 23.30826 \\
\hline \multicolumn{8}{|l|}{ Tunisia } \\
\hline & 0 & -241.8991 & NA & 4107.571 & 19.67192 & 19.86694 & 19.72601 \\
\hline & 1 & -206.9408 & $55.93316^{*}$ & 921.1464* & $18.15527 *$ & $19.13037^{*}$ & $18.42572 *$ \\
\hline & 2 & -194.4557 & 15.98100 & 1366.534 & 18.43645 & 20.19164 & 18.92327 \\
\hline & 3 & -184.2596 & 9.788222 & 2980.894 & 18.90077 & 21.43603 & 19.60394 \\
\hline & 4 & -162.4143 & 13.98100 & 3922.747 & 18.43314 & 21.74849 & 19.35268 \\
\hline
\end{tabular}

\section{Source: calculation made on eviews 9.0 .}

* indicates lag order selected by the criterion

LR: sequential modified LR test statistic (each test at $5 \%$ level)

FPE: Final prediction error

AIC: Akaike information criterion

SC: Schwarz information criterion

We recognize that the number of lags that minimize the criteria « $\mathrm{AlC}$ » and « $\mathrm{SC}$ » is $\mathrm{P}=1$ for Algeria, Morocco and Tunisia.

So now we can estimate the long-term relationship between economic growth and financial integration by the ARDL approach. Table $\mathrm{N}^{\circ} 3$ of the test of Bounds summarizes this long-term relationship.

Table $N^{\circ} 3$ : the Bounds testing analysis

\begin{tabular}{|l|l|l|}
\hline Countries & lag & F-statistics \\
\hline Algeria & 1 & 4.175683 \\
\hline Marrocco & 1 & 16.25216 \\
\hline Tunisia & 1 & 15.13850 \\
\hline Critical Bounds values & \multicolumn{2}{|c|}{ Lag 1 } \\
\cline { 2 - 3 } & $\mathrm{I}(0)$ & $\mathrm{I}(1)$ \\
\cline { 2 - 3 } $10 \%$ & & 3.77 \\
$5 \%$ & 2.72 & 4.35 \\
$2.5 \%$ & 3.23 & 4.89 \\
$1 \%$ & 3.69 & 5.61 \\
& 4.29 & \\
\hline
\end{tabular}

\section{Source: calculation made on eviews 9.0 .}

We find that the coefficient of F-statistics of Tunisia and Morocco (calculated $\mathrm{F}$ of Tunisia $=15.13850$ and Morocco=16.25216 ) exceeds the critical values of $10 \%, 5 \%, 2.5 \%$ and $1 \%$ of Bounds test. While for Algeria, the coefficient F-statistics (calculated $\mathrm{F}=4.175686$ ) exceeds the critical values of $5 \%, 2.5 \%$ and $1 \%$ of Bounds test, which examines the long-term relationship between economic growth and financial integration for these three countries. Therefore, we conclude that the long-term relationship exists. 
Table $N^{\circ} 4$ : Long Run Coefficients

\begin{tabular}{|c|c|c|c|}
\hline \multicolumn{4}{|c|}{ Dependent variable : GDP } \\
\hline & Variables & Coefficients & Probabity \\
\hline \multirow[t]{3}{*}{ Algeria } & FI & 1.774888 & 0.0007 \\
\hline & TO & 0.051896 & 0.0238 \\
\hline & RI & 1.002059 & 0.0001 \\
\hline \multirow[t]{3}{*}{ Marrocco } & FI & 0.795844 & 0.0027 \\
\hline & TO & 0.000259 & 0.0210 \\
\hline & RI & 0.502599 & 0.0010 \\
\hline \multirow[t]{3}{*}{ Tunisia } & FI & 0.118148 & 0.0015 \\
\hline & TO & 0.015831 & 0.0693 \\
\hline & RI & 0.479910 & 0.0028 \\
\hline
\end{tabular}

Source: calculation made on eviews 9.0 .

Table $\mathrm{N}^{\circ} 4$ presents the existence of a positive and significant relationship between macroeconomic policy (interest rate on deposits) and economic growth (GDP) for the three countries, however, the relationship between the second variable of macroeconomic policy (trade openness) and economic growth is positive but not significant. Also, we recognize that the long-term relationship between economic growth and financial integration variable is positive and significant.

\section{CONCLUSION}

Using ARDL approach to study the long-term relationship between economic growth and financial integration, we come to the conclusion that financial integration has a long-term positive influence on economic growth. As well as the macroeconomic policy followed by the Maghreb countries (Tunisia, Algeria and Morocco) helps a lot to boost economic growth. Bounds test's results clearly demonstrate the importance of the determination of a macroeconomic policy, which encourages an economy to well integrate, financially, on the global market that has a great effect on economic growth. We find that trade openness and interest rates on deposits have a positive impact on economic growth even though openness value is not significant. So, financial liberalization increases the interest rate on deposits, which leads to increase the savings rate of an economy, since this rise of the interest rate reduces projects of low-output and helps to develop the financial sector that plays an important role in economic growth. Finally, we can conclude that without a good macroeconomic policy an economy cannot integrate financially, and subsequently cannot act positively on economic growth.

\section{References}

Ahmed, A. D. (2011). "International Financial Integration, Investment and Economic Performance in Sub-Saharan African Countries". Global Economy Journal, Vol. 11, Issue 4, Article 5.

Alesina 1994; Alberto Alesina \& Roberto Perotti (1994), « The Political economy of growth : a critical survey of the recent litterature », The World Bank Economic Review, vol. 8 n³, pp. 351-371.

Arjana Brezigar-Masten, Fabrizio Coricelli and Igor Masten, (2011), "Financial integration, banking crises and the credit crunch", working paper.

Batra, R. (1992), "The fallacy of free trade", Review of International Economics, Vol. 1, pp

Bekaert, G. H., C. R. Harvey et Lumblad (2005), "Does financial liberalization spur growth?," Journal of Financial Economics, Vol. 77, $\mathrm{N}^{\circ} 1$, pages 3-55, July.

Brezigar-Masten, A., F. Coricelli and I. Masten (2008), “Non-linear Growth Effects of Financial Development: Does Financial Integration Matter", Journal of International Money and Finance Vol. 27 No. 2.

Chan-Lau, J. A. and Chen (2001), "Crash-Free Sequencing Strategies for Financial Development and Liberalization", IMF Staff Papers, Vol. 48, $\mathrm{N}^{\circ} 1$.

De Gregorio, J. (1996), “Borrowing constraints, human capital accumulation, and growth”, Journal of Monetary Economics 37, 49-71. 
De Grilli et Milesi-Ferretti (1995), “Development and Liberalization", IMF Staff Papers, Vol. 48, Nº 1.

Dutz Mark (1991), "Firm output adjustment to trade liberalization : Theory with application to the Morocan experience", World Bank. Economies Different ?", NBER Working Paper, № 8076.

Edison, Hali J. \& Levine, Ross \& Ricci, Luca \& Slok, Torsten (2002), "International financial integration and economic growth", Journal of International Money and Finance, Vol. 2, Nº 6, pages 749-776.

Edwards S. (2001), "Capital Mobility and Economic Performance: Are Emerging Economies Different ?", NBER Working Paper, $\mathrm{N}^{\circ} 8076$.

Eozenou (2008), "Financial Integration and Macroeconomic Volatility: Does Financial Development Matter", MPRA, September.

Fecher, F., Kessler, D., Perelman, S, et Pestieau, P. (1993), " Productive performance of the French insurance industry", Journal of Productivity Analysis, Vol 4, pp 77-93. financial integration and economic growth", Journal of International Money and Finance,

Galbis. V (1977) financial intermediation in Economic Growth in Less Developed Countries : a theoretical approach, Journal of developpement Studies. 71 (3), 393-410.

Grossman, G.M. et Helpman, E. (1991), "Innovation and growth in the global economy", Cambridge, MIT Press, Boston.

Grossman, Gene M. and Helpman, Elhanan. (2014). “Growth, Trade and Inequality,” National Bureau of Economic Research Working Paper No. 20502.growth?," Journal of Financial Economics, Vol. 77, N 1, pages 3-55, July.

Haddad Mona (1993), "The link between trade liberalization and multi-factor productivity : The case of Morocco", Middle East et North Africa Discussion Paper $N^{\circ} 4$.

Harrison, A. (1996), "Openness and growth, a time-series, cross-country analysis for developping countries", Journal of Development Economics, Vol 48, N², pp 419-447.

Henry, P. (2000), "Do stock market liberalisation cause investment booms", Journal of Financial Economics, Vol 58, pp 301-334.

Honig (2008), "Addressing Causality in the Effect of Capital Account Liberalization on Growth", Journal of Macroeconomics, pp 1-15.

Kapur, (1976), "Alternative Stabilization Policies for Less Developed Economics", Journal of Political Economy, Vol $84, \mathrm{~N}^{\circ} 4$.

King and Levine (1993 b), "Finance and Growth: Schumpeter Might Be Right", The World Bank Working Papers, $\mathrm{N}^{\circ} 1083$, February.

Klein et Olivier 2008, "Capital account liberalization, financial depth, and economic growth", Journal of International Money and Finance, Volume 27, Issue 6, pp 861-875.

Klein M. W., Olivei G. P. (1999), "Capital account liberalization, financial depth, and economic growth", NBER Working Paper, August.

Kraay A. (1998), "In Search of the Macroeconomic Eff ects of Capital Account Liberalization", World Bank. Lane et Milesi-Ferretti, (2003), “International Financial Integration,” Staff Papers, Vol. 50 (Special Issue), pp. 82113.

Leamer, E. (1985), "Vector autoregressions for causal inference ?", Carnegie-Rochester Conference Series on Public Policy, Vol 22, pp 255-303.

Levchenko, A. A., Rancière, R. et T. Mathias (2008), "Growth and Risk at the Industry Level: the Real Effects of Financial Liberalization," CEPR Discussion Papers 6715, C.E.P.R. Discussion Papers.

Levine, R. (2001), "International Financial Liberalization and Economic Growth", Review of International Economics, Vol. 9, $\mathrm{N}^{\circ} 4$, pages 688-702, November.

Levine, R. et Zervos, S., (1998), “Stock Markets, Banks, and Economic Growth”, American Economic Review, 88 (3), 537-558.

M KchirJedidi\& S. Mensi (FSEG Tunis -Université El Manar -Tunisie) : "Ouverture du compte de capital et ordonnancement des réformes économiques et financière", VIIèmesJournées d'Economie Financière El MouradiGammarthTunis 14 et 15 octobre 2010 La régulation de la finance mondiale Quelles perspectives pour l'après-crise? 
Manganelli, S., and Popov, A. (2010), "Financial markets, diversification, and allocative efficiency: International evidence", ECB Working paper.

Mckinnon, R.I (1973), " Moneny and capital in economic development", the brookings institution, Washington.

Mougani (2012), "An Analysis of the Impact of Financial Integration on Economic Activity and Macroeconomic Volatility in Africa within the Financial Globalization Context". African Development Bank Group, Working paper $\mathrm{N}^{\circ} 144$.

O’Donnell, B. (2001), "Financial Openness and Economic Performance", Trinity College, Dublin, Ireland (non publiee).

Obstfeld, M., (1994), "Risk-taking, Global Diversification, and Growth", American Economic Review, N 84, pp 1310-1329.

Ousama Ben Salha, Tarek Bouazizi et Chaker Aloui, (2008)," Libéralisation Financière, Crises Bancaires et Croissance Économique : Cas des Pays du Sud de la Méditerranée ", Colloque international « Ouverture et émergence en Méditerranée », octobre 2008 Rabat, Maroc.

Sami Mansi , Léandre Bassole and Gilhaimé Mouanda-Mouanda(2010), "L'intégration financière, l'instabilité financière et la croissance économique : Spécifications et estimations en données de panel", working paper $\mathrm{N}^{\circ} 82$, Commission économique pour l'Afrique.

Prasad E., Rogo.K., Wei Shang-Jin et Kose M. Ayhan. (2003), "Effets de la mondialisation financière sur les pays en développement: Quelques constatations empiriques", p.39-52.

Quinn. (1997): "The Correlates of Changes in International Financial Regulation", American Political Science Review, vol. 91, pp. 531 - 551.

Razafindrakoto, M., Roubaud, F. (2005)," Les multiples facettes de la pauvreté dans un pays en développement : le cas de la capitale malgache", Économie et Statistique, pp 131-155.

Rivera-Batiz, L. A. et P. M. Romer (1991), "International trade with endogenous technological change,"European Economic Review, Elsevier, Vol 35, N4, pp 971-1001.

Rodrik D. (1998), "Who Needs Capital Account Convertibility ? " , in Peter Kenen,ed », Should the IMF Pursue Capital-Account Convertibility? », Princeton Essays in International Finance, $N^{\circ} .207$.

Romer, P. (1993), "Idea gaps and object gaps in economic development", Journal of Monetary Economics, Vol 32, $N^{\circ} 3$.

Shaw, E. (1973), "Financial deepening in economic development", New NYork : Oxford University Press.

Tybout James (1991), "Linking trade and productivity new research directions", The World Bank Economic Review, Vol 6. pages 749-776.

Zenasni Soumia et Benhabib Abderrezak, (2012), “ L'intégration financière : contrainte et/ou opportunité pour la croissance économique des pays de l'Union du Maghreb Arabe (UMA) “ disponiblz sur le site www.univeloued.dz/roa/images/PDF/B12.pdf. 